\title{
Current Status and Future Prospects of China's Peer-to-Peer Lending Regulation
}

Hang Yin

\begin{abstract}
China's peer-to-peer lending industry is now at a critical moment that the Draft Measures on P2P lending regulation has just been Hang Yin

put forward, determining the industry's future direction of development. This research is going to analyze the current status of China's P2P lending market and its regulation first. Then comparing China with the US and the UK in terms of P2P lending business models and regulation. Finally combining China's own features and the US \& UK's experiences to find out the problems with China's P2P lending regulation and provide corresponding recommendations to solve the problems.
\end{abstract}

Keywords: Current Status, Future Prospects, China, Peer-toeSciencePublisher Peer, Regulation eSciPub LLC, Houston, TX USA. Website: http://escipub.com/ 


\section{Research background}

Peer-to-peer lending is a new mode of financing that allows borrowers and lenders to transact through Internet platform without traditional intermediaries (Hulme and Wright, 2006). This industry was originated from the United Kingdom with the first P2P platform Zopa founded in 2005. Then it sprang up in the United States and attracted extensive attention. It wasn't introduced into China until 2007, in which year Paipaidai was founded. With the astonishingly fast development of Internet finance in China from 2013, China's P2P industry has experienced an incredible growth and has become number one in the world in terms of platforms' amount and the loan scale.

With the philosophy of inclusive finance, P2P lending pays close attention to the long tail market, providing individuals and middle \& small enterprises with lower financing thresholds and costs; meanwhile, providing ordinary people with a convenient and relatively high-yield wealth management channel. Peer-to-peer lending works really well in satisfying both borrowers' and lenders' needs, improving Chinese financial market system further. However, the lack of barriers to entry, industrial standards, and regulation in previous years had made China's P2P lending market be filled with good and evil. Problem platforms emerged one after another, some of which were related to self-financing, malicious frauds, or operational difficulties. In a recent sensational fraud case, the platform Ezubao ran a Ponzi scheme to raise 7.6 billion USD illegally (Reuters, 2016). Similar events damaged investors' interests and confidence as well as the whole industry's further development greatly. A thorough and effective regulatory system is crucial to $\mathrm{P} 2 \mathrm{P}$ lending industry's healthy growth. The release of the Draft Measures on P2P lending regulation in last December indicated that the wild-growing P2P lending industry in China is starting to enter into a subtle regulatory era.

Internet finance industry poses a huge challenge to regulators, as it is a brand new thing with many unforeseen characteristics and has high iteration speed. China's regulatory system has many blank and gray areas for Internet finance. To solve the problems that the emerging industry brought to market, and to obtain its healthy and farsighted growth, proper regulation is essential. On the one hand, regulation should not be so excessive that deprives P2P lending's innovation space. On the other hand, it should not be so absent that leads to high level of industrial risk and disorderly competition. P2P lending industry 
cannot live without both safe and efficient regulation. Well regulated $\mathrm{P} 2 \mathrm{P}$ lending will play a vital role in improving individuals and middle \& small enterprises' financing environment, optimizing financial resources allocation, enhancing financial system's tolerance, and developing inclusive finance. Nevertheless, inappropriate regulated or unregulated $\mathrm{P} 2 \mathrm{P}$ lending platforms will be easy to gather risks, damaging consumers' rights and interests.

To sum up, P2P lending forms an important part of inclusive finance, which is helpful to improve China's financial system. Furthermore, regulation holds the key to developing $\mathrm{P} 2 \mathrm{P}$ lending industry. For this reason, the research on $\mathrm{P} 2 \mathrm{P}$ lending regulation is necessary.

\section{Research aim}

China's peer-to-peer lending industry is now at a critical moment that the Draft Measures on $\mathrm{P} 2 \mathrm{P}$ lending regulation has just been put forward, determining the industry's future direction of development. This research is going to analyze the current status of China's P2P lending market and its regulation first. Then comparing China with the US and the UK in terms of $\mathrm{P} 2 \mathrm{P}$ lending business models and regulation. Finally combining China's own features and the US \& UK's experiences to find out the problems with China's P2P lending regulation and provide corresponding recommendations to solve the problems.

\section{Research methodology}

\section{Judgmental sampling method}

Judgmental sampling is the sampling method where the researcher selects the sample from the population based on their own judgment (Explorable, 2009). When analyzing China's $\mathrm{P} 2 \mathrm{P}$ lending business models, the population is 2349 operating platforms up to the end of June (WDZJ, 2016). This research selects the top 100 platforms from WDZJ ranking in outstanding loan amount. The reason why choosing this indicator is that it best presents the current market's situation. Although the sample only constitutes a little more than $4 \%$ of the population, these 100 platforms occupy $72 \%$ of industry total outstanding loan volume. In addition, China's P2P lending industry has the character of homogenization, with small platforms simulating large platforms from every aspect. Therefore, these sample platforms have strong representativeness in analyzing the business models.

\section{Comparative analysis}

Comparing China, the US and UK's P2P lending business models and regulatory systems to conclude each country's advantages and disadvantages. Using the US and UK'S JME: http://escipub.com/journal-of-modern-economy/ 
relatively mature experiences for reference on improving China's P2P lending regulation.

\section{Normative analysis}

Normative statements are claims that attempt to prescribe how the world should be (Mankiw, 2014). The statements are based on certain value judgments and standards. When analyzing the problems and solutions with China's P2P lending regulation, this method will be used.

\section{Research data}

\section{China's P2P lending industrial data}

The data on China's P2P lending industry scale, maturity, yield rate, and so on is from WDZJ and P2PEye, which are two most authoritative P2P lending data organizations in China. The industrial data reflects China's P2P lending market's development process, providing a foundation for the following research.

\section{China's P2P lending platforms' business models}

P2P lending businesses are observed from platforms' official websites. The top 100 platforms from WDZJ ranking in terms of the outstanding loan amount will be analyzed out of the consideration of representativeness and workload.

\section{Research contribution}

\section{Research under a new environment}

The CBRC released the Draft Measures on P2P lending in December 2015, becoming a milestone of China's P2P lending regulation. New rules lead to a new regulatory environment, which deserves new researches to study on. Additionally, the tentative rules need professional comments and suggestions widely in this transitional period in order to regulate the industry more appropriately. However, the current researches on China's P2P lending regulation are relatively lagging, not including the analysis of the new regulatory environment with newly released rules. By contrast, this research is just analyzing the regulation problem under the new environment, presenting a more accurate status quo of China's P2P lending regulation and making more targeted recommendations on improving the regulatory system. This paper is helpful to update the researches on China's P2P lending regulation.

\section{Suggestions on specific rules}

The current researches on China's P2P lending regulation most make suggestions on the regulatory system's establishment from a macro perspective. Macro-level suggestions are beneficial to construct the framework of a regulatory system, but actually, the basic frame 
structure of China's P2P lending regulation has been confirmed. Therefore, suggestions on specific rules rather than macro environment have more practical values. This research makes recommendations mainly on the Draft Measures, ensuring the suggestions are targeted and exercisable. This paper's suggestions to improve China's P2P lending regulation and their supporting theories enrich the researches on $\mathrm{P} 2 \mathrm{P}$ lending regulation problem.

\section{New classification method of P2P lending business models}

Not like most other researches that simply divide P2P lending business models into the online or offline mode, this research analyzes $\mathrm{P} 2 \mathrm{P}$ lending businesses from the perspective of asset side, platform side, and liability side. These three sides can fully reflect the whole and coherent business process in $\mathrm{P} 2 \mathrm{P}$ lending. This classification method is helpful to understand P2P lending businesses more visually and completely, enriching the researches on $\mathrm{P} 2 \mathrm{P}$ lending business models.

\section{Research weakness}

\section{Data quality}

$\mathrm{P} 2 \mathrm{P}$ lending in China is an emerging industry, which does not have unified information disclosure rules. Platforms disclose different types, forms, and contents of data. This increases the statistical difficulty and decreases the reliability of collected data.

\section{Lack of empirical analysis}

This research mainly uses qualitative analysis to study the $\mathrm{P} 2 \mathrm{P}$ lending regulation problem. Some opinions might be subjective without empirical support, decreasing the research's credibility.

\section{References}

[1] Explorable. (2009). Judgmental Sampling. Retrieved 24 July, 2016, from https://explorable. com/judgmental-sampling

[2] Hulme, M. K., \& Wright, C. (2006). Internet based social lending: Past, present and future. Social Futures Observatory, 115.

[3] Mankiw, N.G. (2014). Principles of Economics. (7th ed.). Boston: CENGAGE Learning.

[4] Reuters. (2014). UPDATE 1-In China, troubled shadow bank product tests no-default policy. Retrieved 22 July, 2016, from http://in.reuters. com/article/china-icbc-idINL3NOKQ2L520140116

[5] Reuters. (2016). China police arrest 21 over $\$ 7.6$ bln online financial scam. Retrieved 21 July, 2016, from http://www.reuters.com/article/china-fraud-ezubao-arrestidUSKCNOVA1E5

[6] WDZJ. (2016). 2016 China's P2P lending industry semiannual report. Retrieved 22 July, 2016, from http://www.wdzj.com/news/baogao/30277-all.html

[7] WDZJ. (2016). P2P lending platform data. Retrieved 25 July, 2016, from http://shuju.wdzj.com/platdata-1.html 